\title{
INTRODUCTION
}

\section{Seabird responses to a changing Bering Sea}

\author{
Alexander S. Kitaysky ${ }^{1, *}$, George L. Hunt $\mathrm{Jr}^{2}$ \\ ${ }^{1}$ Department of Biology and Wildlife, Institute of Arctic Biology, University of Alaska Fairbanks, Fairbanks, \\ AK 99775-7000, USA \\ ${ }^{2}$ School of Aquatic and Fishery Sciences, University of Washington, Box 355020, Seattle, WA 98195, USA
}

\begin{abstract}
The eastern Bering Sea is well known for its spatial and temporal variability. Significant inter-annual changes in the abundance of zooplankton and forage fish are related to the timing of sea ice retreat. In this Theme Section, studies explore how different species and communities of seabirds inhabiting the region respond to contrasting patterns of spring sea-ice-retreat and summer temperatures. Data from the pelagic realm are used to explore climate-linked variability in the responses of seabird distributions to years with early and late sea-ice-retreat. Colony-based studies, relying on bird-borne data loggers and physiological parameters, examine how long-term changes in the foraging and migratory behaviors of individuals during cold and warm years may affect birds breeding on the Pribilof Islands (Alaska, USA). A unique aspect of this Theme Section is the availability of both colony-based and pelagic studies of seabirds that overlap in space and time. This body of work aims to provide an overview of seabird responses to oceanographic variability in the eastern Bering Sea, spanning a period of $100 \mathrm{yr}$ and an immense oceanographic region.
\end{abstract}

KEY WORDS: Climate change - Ship surveys $\cdot$ Logger technology $\cdot$ Historical ecophysiology · Food-web stability $\cdot$ Nutritional stress

\section{Introduction}

The publication of this Theme Section comes as western Alaska is in the midst of its warmest winter and headed for the lowest winter sea-ice coverage in the recorded history of the Bering Sea (http://nsidc. org/data/seaice_index). Modeling studies forecast a reduction of winter sea-ice coverage in the Bering Sea in response to climate warming (Hermann et al. 2016). The major ecological challenge is to predict how such warming will affect Bering Sea ecosystems and the marine predators inhabiting the region. The potential impacts of future climate warming on marine ecosystems can be assessed by examining the effects of present-day and historical variations in climate. Understanding the effects of environmental change on seabirds requires the identification of

*Corresponding author: askitaysky@alaska.edu region-specific responses and baselines that may act as reference conditions. Papers in this Theme Section focus on multi-decadal records of seabird responses to climate variability in the southeastern Bering Sea. The overarching goal is to explore how different species and communities of seabirds respond to contrasting patterns of spring sea-ice retreat and summer temperatures.

There are 2 broad themes covered in this Theme Section. The first, examined by Hunt et al. (2018), focuses on how the distribution and abundance of potential seabird prey are affected by climate variability via the timing of sea-ice retreat, and how these impacts on prey have affected the distributions of seabirds over the southeastern Bering Sea shelf since the mid-1970s. The second theme, addressed by colony-based studies relying on bird-borne data

() The authors 2018. Open Access under Creative Commons by Attribution Licence. Use, distribution and reproduction are unrestricted. Authors and original publication must be credited. 
loggers (Kokubun et al. 2018, Orben et al. 2018), stable isotopic niche dynamics (Will \& Kitaysky 2018) and physiological tools (Kokubun et al. 2018, Orben et al. 2018, Will et al. 2018), examines changes in the foraging behavior of individual seabirds and provides a mechanistic perspective on how and why environmental conditions in cold and warm years affect breeding and wintering birds. Reliance on long-term data series and the use of integrative approaches allows these colony-based studies to establish reference points and describe seabird responses to climate variability in a comprehensive way (e.g. spatial, temporal and in the context of seabird communities and individuals).

\section{Seabird responses to environmental variability}

Seabirds are sensitive to the spatial and temporal variability of their environment, especially the distribution and abundance of their prey. In the Bering Sea, particularly over the middle portion of the southeastern shelf, the recruitment of large, lipid-rich zooplankton varies with the timing of sea-ice retreat and the availability of ice algae in spring (Wang et al. 2015, Hunt et al. 2016, Sigler et al. 2016). The abundance of these zooplankton, in turn, affects the production and abundance of forage fish (e.g. Eisner \& Yasumiichi 2017). Non-breeding seabirds are able to shift their foraging efforts to favorable locations within a region, or depart from that region altogether (e.g. Hunt \& Harrison 1990, Coyle et al. 1992, Hunt et al. 1998, 2018, Nishizawa et al. 2017). However, seabird breeding colonies are fixed in place, and location-specific responses to climate (e.g. Gaston et al. 2005, Frederiksen et al. 2007) have the potential to complicate prediction of the effects of climate change (Brown et al. 2011), thereby preventing us from making generalizations (but see Satterthwaite et al. 2012). Papers in this Theme Section show that the ability of breeding seabirds to take advantage of changing food resources depends on a colony's location (Kokubun et al. 2018), the partitioning of food resources by members of the foraging guild and the heterogeneity of foraging habitat within reach of breeding seabirds (Will \& Kitaysky 2018; also see Barger \& Kitaysky 2012, Barger et al. 2016, and Kokubun et al. 2016), and the degree of foraging specialization of a particular species (Orben et al. 2018, Will et al. 2018).

Understanding the effects of climate variability on seabirds benefits from both long time-series and from an integrated research approach. Specifically, since climate change is likely to affect seabird food resources, it is essential that we are not only able to detect changes in food availability, but also to predict how those changes will affect breeding and wintering seabirds. In this regard, determination of the nutritional state of an individual and its effects on both reproduction and survival are needed. Physiological measurements, and in particular stress hormones (e.g. corticosterone) with known correlations with food supply and survival (e.g. Romero \& Wikelski 2001, Brown et al. 2005, Blas et al. 2007, Kitaysky et al. 2007, 2010, Satterthwaite et al. 2010, Will et al. 2015), provide a practical method for assessing seabird responses to climate change in data-limited systems (Vincenzi \& Mangel 2014). Three of 5 studies in this Theme Section use changes in corticosterone as a 'quantifier' of changes in food abundance on annual (Orben et al. 2018), decadal (Kokubun et al. 2018), and century scales (Will et al. 2018), which allowed them to interpret the effects of warm oceanographic conditions on seabirds at their breeding and wintering grounds.

In the continental shelf regions of the southeastern Bering Sea with seasonal ice cover, shifts between warm years with early sea-ice retreat and cold years with late sea-ice retreat result in foraging conditions that favor either piscivores (warm years) or planktivores (cold years). In recent years with early sea-ice retreat, age-0 walleye pollock Gadus chalcogrammus have been abundant in the near-surface waters of the southeastern Bering Sea (e.g. Renner et al. 2016, Hunt et al. 2018). This availability of prey improved foraging conditions for the piscivorous black-legged kittiwakes Rissa tridactlya and thickbilled murres Uria lomvia breeding on the Pribilof Islands (Alaska, USA; Satterthwaite et al. 2012, Kokubun et al. 2018). In contrast, in these warm years, the abundance of large, lipid-rich zooplankton over the middle shelf was reduced, leading to food stress in planktivores such as the least auklet Aethia pusilla, also nesting at the Pribilof Islands (BenowitzFredericks et al. 2008, Dorresteijn et al. 2012).

A similar situation occurs in the northern Sea of Okhotsk. There, contrasting patterns in food availability to sympatrically breeding planktivorous and piscivorous seabirds of Talan Island (Russia) have been reported since the mid-1980s, with warm oceanographic conditions being detrimental to planktivorous but beneficial to piscivorous seabirds (Kitaysky \& Golubova 2000). Formerly, the Talan colony has been home to a thriving population of planktivorous crested auklets Aethia cristatella. As winter ice coverage dramatically decreased in the Sea of 
Okhotsk, so did the crested auklet population of Talan Island (Andreev et al. 2010). Whether this might be a future scenario for planktivorous seabirds breeding in other regions of the North Pacific, including the southeastern Bering Sea, demands future focused investigation.

\section{Distributions in cold and warm years}

In this Theme Section, we take advantage of an unusual opportunity to compare and contrast shifts in seabird foraging distributions in warm and cold years, as seen from both at-sea observations and from the tracking of individuals from colonies. Data were available for 4 species of seabirds: red-legged kittiwake Rissa brevirostris, black-legged kittiwake, common murre Uria aalge and thick-billed murre.

Changes in the foraging distribution of red-legged kittiwakes during the breeding season were examined in 2 studies that used different approaches and time series, yet provided similar results. Hunt et al. (2018), working with a 4-decade-long pelagic data set (Fig. 1), found that red-legged kittiwakes made a fairly minor shift from deep basin waters to shallower waters in warm years. Will et al. (2018), using stable isotopes from a 100 yr data set based on museum specimens, found that breeding red-legged kittiwakes remained foraging in the ocean basin during warm years. These results provide evidence that redlegged kittiwakes do not usually adjust their foraging habits in response to a short-term climate variability and do not take advantage of the juvenile pollock subsidies available to them in the vicinity of the breeding colony during warm years. This relative inflexibility in foraging behavior might make them vulnerable to climate warming.

In Hunt et al. (2018), the at-sea distributions of both black-legged kittiwakes and common murres were centered on the inner shelf in cold years and shifted toward the middle shelf in warm years. These shifts may be comparable to those recorded for these 2 species by Will \& Kitaysky (2018), who found in colonybased studies that these 2 species shift their foraging from basin waters to shelf waters in warm years. In warm years with early sea-ice retreat, middle and outer shelf waters have abundant age- 0 walleye pollock in near-surface waters (Hunt et al. 2018), and this source of prey was likely attractive to the 2 piscivorous bird species. Likewise, 3 contributions to this Theme Section found that the off-shelf-foraging thick-billed murres shifted their foraging to shelf

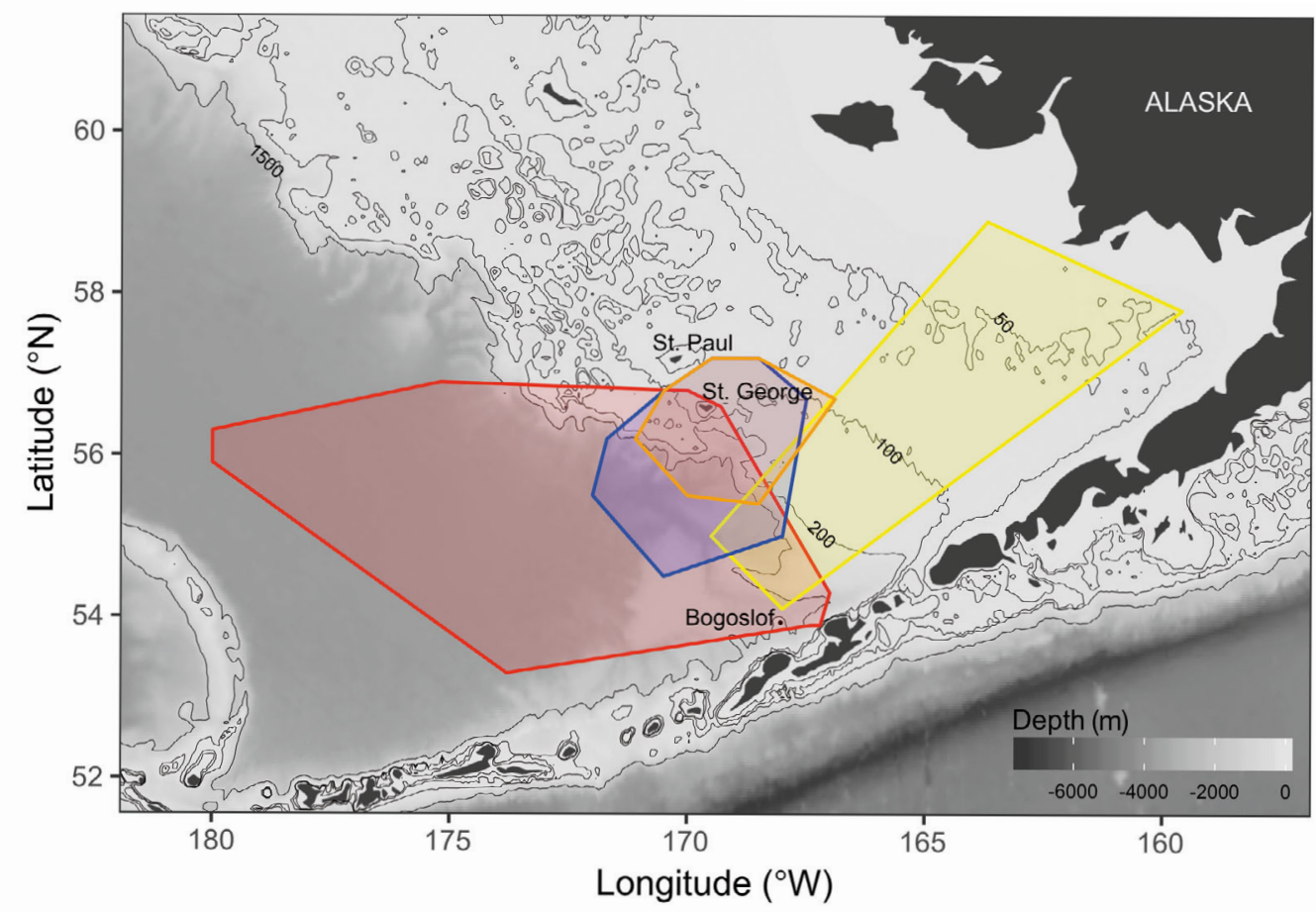

Fig. 1. Southeastern Bering Sea showing Bogoslof Island and the Pribilof Islands (St. Paul and St. George Islands). The yellow polygon approximates the area from which Hunt et al. (2018) obtained data on the pelagic distribution of seabirds. The other polygons approximate the foraging areas used by seabirds nesting on St. George Island as determined from GPS tracks: orange, thick-billed murre (Kokubun et al. 2018); blue, black-legged kittiwake (Paredes et al. 2014); red, red-legged kittiwake (Yamamoto et al. 2016; R. Orben, unpubl. data). Map courtesy of Rachael Orben 
waters in warm years (Hunt et al. 2018, Kokubun et al. 2018, Will \& Kitaysky 2018), again possibly because of the availability of age- 0 walleye pollock there.

These apparent similarities among different studies indicate that shifts in foraging distributions of seabirds are a widespread phenomenon in the southeastern Bering Sea. The shift into the shelf regions was associated with an improvement of foraging conditions for thick-billed murres and black-legged kittiwakes breeding on the Pribilof Islands, as reflected in the improvement of their nutritional state (Satterthwaite et al. 2012, Kokubun et al. 2018). However, warm conditions have not been uniformly beneficial to piscivorous seabirds in all southeastern Bering Sea colonies. Studies of seabirds on Bogoslof Island, a large breeding colony located in the basin off the continental shelf (Fig. 1), have shown that black-legged kittiwakes and both species of murres experienced higher nutritional stress during warm years (Barger \& Kitaysky 2012, Satterthwaite et al. 2012). Seabirds nesting on Bogoslof Island tend to forage close to the island, often over deep basin waters, or along the coasts of the nearby Aleutian Islands (e.g. Paredes et al. 2012, Harding et al. 2013). These areas support a different suite of forage fish than the continental shelf (Paredes et al. 2012) with its high abundance of walleye pollock, and warm upper-ocean conditions over the basin may not be favorable for the fish found there (see also Hunt et al. 2018). Thus, the shift in distribution of surface-foraging species from basin waters to the shelf edge or farther on-shelf, documented by Hunt et al. (2018), might be associated with worsening foraging conditions over the basin in warm years, at least for some species of breeding seabirds.

This Theme Section adds considerably to our understanding of the pelagic ecology of the red-legged kittiwake, an IUCN listed 'Vulnerable' species (BirdLife International 2017) endemic to the Bering Sea. Red-legged kittiwakes remain specialized foragers on oceanic prey during reproduction (Kokubun et al. 2015, Yamamoto et al. 2016) and associate with deep ocean-basin water areas during wintering (Orben et al. 2018). The paper by Will et al. (2018) shows that during 1913 to 2015, warmer oceanographic conditions during the late breeding and wintering seasons have been beneficial to red-legged kittiwakes breeding on St. George Island (Pribilof Islands; Fig.1). Stress and stable isotopic signatures reflect foraging conditions that red-legged kittiwakes experience during 2 specific periods: the end of reproduction ( August to September) and prior to the spring migration back to the breeding colony ( February) (Orben et al. 2018). Will et al. (2018) report that foraging conditions between these 2 seasons are highly auto-correlated, suggesting that oceanographic processes affecting food supplies of breeding red-legged kittiwakes may carry over from the late summer to the following winter. At the same time, there seems to be no connection between the late winter and the following summer (Will et al. 2018). Since birds experience less stress during warm winters and during the period of population growth (Will et al. 2018), one might expect that warm oceanographic conditions during the winter would also be associated with a high performance of redlegged kittiwakes during the subsequent breeding season. However, this is not the case, as multidecadal observations of reproductive performances in the St. George Island colonies show that the reproductive failure of red-legged kittiwakes is usually associated with the failure of birds to lay eggs during warm years with early ice retreat (Byrd et al. 2008).

\section{Summary and future directions}

This Theme Section summarizes much of our current knowledge and establishes reference points for the effects of climate on several species of seabirds breeding on the Pribilof Islands and those foraging in the southeastern Bering Sea. Warm oceanographic conditions have been beneficial to piscivorous seabirds (e.g. thick-billed murres and black-legged kittiwakes) breeding in the Pribilof colonies during the 2 recent decades and have negatively affected planktivorous seabirds (e.g. least auklets) breeding there. The large, lipid-rich copepods, that the auklets feed on, form the base of the regional food web, and if these zooplankton become scarce, the food web of the continental shelf regions of the Bering Sea may become vulnerable to collapse. Such a collapse would have dire consequences for both the seabirds and the fish stocks in the region.

To date, research in the Bering Sea has been dominated by observations from the southeastern Bering Sea shelf. The ecosystems of the shelf-slope, southwestern and ocean basin regions have been largely neglected. More information is needed from these areas. There is also a need for a compilation of existing time series in different regions of the Bering Sea shelf for a comprehensive review of the effects of climate warming on food web structure and productivity, including not only commercially valuable fish stocks, but also upper-trophic-level predators such as seabirds and marine mammals. We need to understand the proximate and ultimate mechanisms by which seabirds 
are adapting to warming conditions if we are to interpret the signals from seabirds and to relate these signals to the responses of zooplankton and fish stocks.

Acknowledgements. This Theme Section could not have been completed without enthusiastic discussions and contributions of their unique long-term datasets by our international team of scientists. We thank Kyle Elliott and Rory Wilson for their professional handling of the peer-review process. We thank Rachael Orben for providing the figure for this Introduction. We also thank Alexis Will and Roman Kitaysky who provided comments that improved earlier drafts. We thank the North Pacific Research Board (NPRB) for their continuous support of our long-term studies in the Bering Sea. The University of Alaska Fairbanks (USA), the National Institute of Polar Research (Japan) and the University of Washington (USA) are thanked for Open Access funding of this Theme Section. NPRB provided partial funding for the contributions of G.L.H. (via grant NPRB 1408) and A.S.K. (via grants NPRB 1410 and 1620). This is NPRB publication \# 668.

\section{LITERATURE CITED}

Andreev AV, Golubova EY, Zubakin VA, Kharitonov SP (2010) The number of sea birds on Talan Island: the 20year trend assessment. Courier of the North-East Scientific Center of the Far Eastern Branch of the Russian Academy of Sciences 2:30-42 (in Russian with English Abstract)

Barger CP, Kitaysky AS (2012) Isotopic segregation between sympatric seabird species increases with nutritional stress. Biol Lett 8:442-445

* Barger CP, Young RC, Will A, Ito M, Kitaysky AS (2016) Resource partitioning between sympatric seabird species increases during chick-rearing. Ecosphere 7:e01447

* Benowitz-Fredericks ZM, Shultz MT, Kitaysky AS (2008) Stress hormones suggest opposite trends of food availability for planktivorous and piscivorous seabirds in 2 years. Deep Sea Res II 55:1868-1876

*BrdLife International (2017) Rissa brevirostris. The IUCN Red List of Threatened Species 2017:e.T22694502A 118920892. www.iucnredlist.org/details/22694502/0

* Blas J, Bortolotti GR, Tella JL, Baos R, Marchant TA (2007) Stress response during development predicts fitness in a wild, long lived vertebrate. Proc Natl Acad Sci USA 104: 8880-8884

Brown CJ, Schoeman DS, Sydeman WJ, Brander K and others (2011) Quantitative approaches in climate change ecology. Glob Change Biol 17:3697-3713

Brown CR, Brown MB, Raouf SA, Smith LC, Wingfield JC (2005) Effects of endogenous steroid hormone levels on annual survival in cliff swallows. Ecology 86:1034-1046

Byrd GV, Sydeman WJ, Renner HM, Minobe S (2008) Responses of piscivorous seabirds at the Pribilof Islands to ocean climate. Deep Sea Res II 55:1856-1867

* Coyle KO, Hunt GL Jr, Decker MB, Weingartner TJ (1992) Murre foraging, epibenthic sound scattering and tidal advection over a shoal near St. George Island, Bering Sea. Mar Ecol Prog Ser 83:1-14

Dorresteijn I, Kitaysky AS, Barger C, Benowitz-Fredericks ZM, Byrd GV, Shultz M, Young R (2012) Climate affects food availability to planktivorous least auklets Aethia pusilla through physical processes in the southeastern Bering Sea. Mar Ecol Prog Ser 454:207-220

Eisner L, Yasumiishi E (2017) Large zooplankton abundance as an indicator of pollock recruitment to age-1 and age-3 in the southeastern Bering Sea. In: Siddon E, Zador S (eds) Ecosystem considerations: status of the Eastern Bering Sea marine ecosystem. North Pacific Fishery Management Council, Anchorage, AK, p 145-148

* Frederiksen M, Edwards M, Mavor RA, Wanless S (2007) Regional and annual variation in black-legged kittiwake breeding productivity is related to sea surface temperature. Mar Ecol Prog Ser 350:137-143

*Gaston AJ, Gilchrist HG, Hipfner JM (2005) Climate change, ice conditions and reproduction in an Arctic nesting marine bird: Brunnich's guillemot (Uria lomvia L.). J Anim Ecol 74:832-841

*Harding A, Paredes R, Suryan R, Roby D and others (2013) Does location really matter? An inter-colony comparison of seabirds breeding at varying distances from productive oceanographic features in the Bering Sea. Deep Sea Res II 94:178-191

*Hermann AJ, Gibson GA, Bond NA, Curchitser EN and others (2016) Projected future biophysical states of the Bering Sea. Deep Sea Res II 134:30-47

*Hunt GL Jr, Harrison NM (1990) Foraging habitat and prey taken by least auklets at King Island, Alaska. Mar Ecol Prog Ser 65:141-150

Hunt GL Jr, Russell RW, Coyle KO, Weingartner T (1998) Comparative foraging ecology of planktivorous auklets in relation to ocean physics and prey availability. Mar Ecol Prog Ser 167:241-259

*Hunt GL Jr, Ressler PH, Gibson GA, De Robertis A and others (2016) Euphausiids in the eastern Bering Sea: a synthesis of recent studies of euphausiid production, consumption and population control. Deep Sea Res II 134:204-222.

*Hunt GL Jr, Renner M, Kuletz KJ, Salo S and others (2018) Timing of sea-ice-retreat affects the distribution of seabirds and their prey in the southeastern Bering Sea. Mar Ecol Prog Ser 593:209-230

Kitaysky AS, Golubova EG (2000) Climate change causes contrasting trends in reproductive performance of planktivorous and piscivorous alcids. J Anim Ecol 69:248-262

*Kitaysky AS, Piatt JF, Wingfield JC (2007) Stress hormones link food availability and population processes in seabirds. Mar Ecol Prog Ser 352:245-258

Kitaysky AS, Piatt JF, Benowitz-Fredericks ZM, Hatch SA, Shultz MT, Kitaiskaia EV, Wingfield JC (2010) Food availability and population processes: severity of nutritional stress during reproduction predicts survival of long-lived seabirds. Funct Ecol 24:625-637

Kokubun N, Yamamoto T, Kikuchi DM, Kitaysky AS, Takahashi A (2015) Nocturnal foraging by red-legged kittiwakes, a surface feeding seabird that relies on deep water prey during reproduction. PLOS ONE 10: e0138850

Kokubun N, Yamamoto T, Sato N, Watanuki Y, Will A, Kitaysky AS, Takahashi A (2016) Foraging segregation of two congeneric diving seabird species (common and thick-billed murres) breeding on St. George Island, Bering Sea. Biogeosciences 13:2579-2591

Kokubun N, Takahashi A, Paredes R, Young RC and others (2018) Inter-annual climate variability affects foraging behavior and nutritional state of thick-billed murres 
breeding in the southeastern Bering Sea. Mar Ecol Prog Ser 593:195-208

Nishizawa B, Matsuno K, Labunski EA, Kuletz KJ, Yamaguchi A, Watanuki Y (2017) Seasonal distribution of short-tailed shearwaters and their prey in the Bering and Chukchi seas. Biogeosciences 14:203-214

Orben RA, Kokubun N, Fleishman AB, Will AP and others (2018) Persistent annual migration patterns of a specialist seabird. Mar Ecol Prog Ser 593:231-245

Paredes R, Harding AMA, Irons DB, Roby DD and others (2012) Proximity to multiple foraging habitats enhances seabirds' resilience to local food shortages. Mar Ecol Prog Ser 471:253-269

Paredes R, Orben RA, Suryan RM, Irons DB and others (2014) Foraging responses of black-legged kittiwakes to prolonged food-shortages around colonies on the Bering Sea shelf. PLOS ONE 9:e92520

Renner M, Salo S, Eisner LB, Ressler PH and others (2016) Timing of ice retreat alters seabird abundances and distributions in the southeast Bering Sea. Biol Lett 12: 20160276

Romero LM, Wikelski M (2001) Corticosterone levels predict survival probabilities of Galapagos marine iguanas during El Niño events. Proc Natl Acad Sci USA 98: 7366-7370

Satterthwaite WH, Kitaysky AS, Hatch SA, Piatt JF, Mangel $M$ (2010) Unifying quantitative life history theory and field endocrinology to assess prudent parenthood in a long-lived seabird. Evol Ecol Res 12:779-792

Satterthwaite WH, Kitaysky AS, Mangel M (2012) Linking climate variability, productivity and stress to demogra- phy in a long-lived seabird. Mar Ecol Prog Ser 454: 221-235

Sigler M, Napp J, Stabeno P, Heintz R, Lomas M, Hunt GL Jr (2016) Variation in annual production of copepods, euphausiids, and juvenile walleye pollock in the southeastern Bering Sea. Deep Sea Res II 134:223-234

*Vincenzi S, Mangel M (2014) Food abundance, kittiwake life histories, and colony dynamics in the Northeastern Pacific: implications of climate change and regime shifts. Mar Ecol Prog Ser 515:251-263

* Wang SW, Budge SM, Iken K, Gradinger RR and others (2015) Importance of sympagic production to Bering Sea zooplankton as revealed from fatty acid-carbon stable isotope analyses. Mar Ecol Prog Ser 518:31-50

Will AP, Kitaysky AS (2018) Variability in trophic level and habitat use in response to environmental forcing: isotopic niche dynamics of breeding seabirds in the southeastern Bering Sea. Mar Ecol Prog Ser 593:247-260

Will A, Watanuki Y, Kikuchi DM, Sato N and others (2015) Feather corticosterone reveals stress associated with dietary changes in a breeding seabird. Ecol Evol 5: 4221-4232

Will AP, Kitaiskaia EV, Kitaysky AS (2018) Red-legged kittiwake feathers link food availability to environmental changes in the Bering Sea. Mar Ecol Prog Ser 593: 261-274

* Yamamoto T, Kokubun N, Kikuchi DM, Sato N and others (2016) Differential responses of seabirds to environmental variability over 2 years in the continental shelf and oceanic habitats of southeastern Bering Sea. Biogeosciences 13:2405-2414 